\title{
RELIGIUSITAS, SPIRITUALITAS, DAN KESEHATAN MENTAL: META ANALISIS
}

\author{
Hepi Wahyuningsih \\ Universitas islam Indonesia
}

\begin{abstract}
A meta-analysis was performed in an attempt b clarify the proposed relationship between religiosity/spirituality and mental health. Specilic focus was given to the issue of definition, measurement, namely, whether diffirences in researchers conceptualizations of religlosity/ispirilualily and mental health could account for the various contradictory findings. Analysis of 20 studies conducted during 6 past years revealed that the definilions of religiosity/spiritualily and mental health utilized by researchers were indeed associated with different types and strengths of the correlations between religiosity/spirituality and mental health. it is found that there are positive correlation among organizational religiosity $(r=0,345)$, non-organizational religiosily ( $r=0,445$ ), intrinsic religiosity $(r=0,227)$, multidimensional religiosity $(r=0,253)$, spirituality $(r=0,470)$, and positive mental health. There are negative correlation among organizational refigiosity $(r=-0,012)$, non-organizational religiosity $(r=-$ $0,188)$, intrinsic religiosity $(r=-0,212)$, multidimensional religiosity $(r=-0,130)$, spirituality $(r=-$ $0,046)$, and negative mental heallth.
\end{abstract}

Keywords: meta-analysis, religiosity, spiriluality, mental health ..

Dewasa ini mulai tumbuh suatu konsensus yang menyatakan bahwa komitmen religius dan praktek keagamaan dapat menguntungkan bagi kesejahteraan fisik dan psikologis (Ellison dan Levin dalam Eliassen dkk, 2005). Meskipun demikian, hasil-hasil penelitian yang telah dilakukan untuk menguji pengaruh religiusitas dan spiritualitas terhadap kesehatan mental bervariasi. Hasil penelitian Commerford dan Reznikoff (1996) menunjukkan bahwa religiusitas intrinsik tidak berkorelasi dengan depresi maupun dengan harga diri, tetapi aktivitas keagamaan bersama orang lain (publik) berkorelasi dengan depresi maupın dengan harga diri. Schafer (1997) menemukan bahwa arti penting agama bag individu menunjukkan korelasi yang positif dengan perasaan tertekan (personal distress), keyakinan akan eksistensi Tuhan memiliki hubungan kurvelinier dengan perasaan tertekan (personal distress). dan perasaan berarti memiliki korelasi negatif dengan perasaan tertekan. Variabel-variabel religiusitas dan spiritualitas yang lain tidak memiliki korelasi dengan perasaan tertekan (ketergantungan pada kekuatan besar, kepercayaan hidup sesudah mati, kepercayaan adanya surga dan neraka, kunjungan ke tempat ibadah, frekuensi berdoa, lahir kembali sebagai kristiani, dan pilihan agama saat ini).

Koenig dkk (1998) menemukan bahwa dimensi religiusitas yang mampu menjadi prediktor bagi cepat pulihnya seseorang dari depresi adalah religiusitas intrinsik, sedangkan dimensi religiusitas yang lain tidak mampu menjadi prediktor (religius organisasional dan religiusitas nonorganisasional). Hasil penelitian Peacock dan Poloma (1999) menunjukkan bahwa hampir semua dimensi religiusitas kecuali doa yang berisi permohonan berkorelasi dengan kepuasan hidup. Dirnensi-dimensi 
religiusitas yang berkorelasi dengan kepuasan hidup adaiah kedekatan dengan Tuhan, pengaiaman berdoa, keanggotaan gereja, kunjungan ke gereja/tempat ibadah, doa mediatif, doa ritual, dan doa yang bersifat percakapan.

Variasi hasil penelitian mengenai pengaruh religiusitas dengan kesehatan mental dapat terjadi karena karakteristik subyek dan aspek pengukuran religiusitas yang berbeda-beda (Eiiassen dkk, 2005). James dan Wells (2003) juga mengatakan bahwa bervarlasinya hasil penelitian mengenal pengaruh religiusitas terhadap kesehatan mental dapat dikarenakan sífat muitidimensional dari religiusitas sehingga menimbulkan dampak yang bermacammacam pada kesehatan mentai. Dalam penelitian mela analisis, Bergins (James \& Wells, 2003) membuktikan adanya hasilhasil penelitian hubungan religiusitas dengan kesehatan mental yang bervariasi bahkan saling bertentangan. Hasil penelitian Bergins (James \& Welis, 2003) menunjukkan bahwa $23 \%$ dari studi menunjukkan adanya hubungan yang negatif, $47 \%$ studi menunjukkan adanya hubungan yang positif, dan $30 \%$ menunjukkan tidak ada hubungan. Hasil review secara sistematik yang dilakukan aleh Wong dkk (2006) terhadap penelitian-penelitian yang meneliti pengaruh religiusitas dan spiritualitas terhadap kesehatan mental pada remaja menunjukkan bahwa dari 20 studi yang ditemukan, 18 $(90 \%)$ studi menunjukkan adanya hubungan positif dan 2 studi ( $10 \%$ ) menunjukkan tidak ada hubungan.

Hasii-hasil peneitian mengenai hubungan religilusitas/spiritualitas dengan kesehatan mentai yang bertentangan dan bervariasi telah mendorong Hackney dan Sanders (2003) untuk melakukan studi meta analisis mengenai hubungan kedua variabel tersebut. Hackney dan Sanders (2003) berasumsi bahwa hasii penelitian yang bermacam-macam tersebut kemungkinan dapat terjadi karena konsep religiusitas dan konsep kesehatan mental yang multidimensionai. Oien karena itu, mereka melakukan meta analisis dengan keseluruhan studi maupun melakukan meta analisis pada keiompok-kelompok studi yang terbentuk berdasarkan dimensi-dimensi religiusitas dan dimensi kesehatan mental. Hasil penelitian menunjukkan bahwa sebagian besar dimensi reiigiusitas berkorelasi positif dengan kesehatan mental. Akan tetapi, berdasarkan uji homogenitas, hasii meta analisis menunjukkan adanya variabel moderator yang mempengaruhi hasii.

Berdasarkan uraian di atas, meskipun hasil peneiitian mengenai hubungan religiusitas/spiritualitas bervariasi atau bahkan bertentangan, tetapi dapat diambil kesimpuian bahwa religiusitas/spiritualitas berkoreiasi dengan kesehatan mental. Oleh karena itu, hipotesis daiam penelitian ini adalah ada hubungan antara religiusitas/spiritualitas dengan kesehatan mental.

\section{DASARTEORI}

\section{DefinisI Religiusitas dan Spirituailtas}

Religiusitas dan spiritualitas sering digunakan secara bergantian. Becker (Sharma, 2006) menyatakan bahwa kata spirituaiitas, keyakinan, dan sifat ketuhanan sering digunakan dalam literatur yang membahas religiusitas. Hal ini terjadi karena adanya tumpang tindih pengertian mengenai religiusitas dengan spiritualitas. Davis dkk (2003) menyatakan bahwa ada tumpang tindih definisi antara religiusitas dan spiritualitas. Hal yang sama juga dikemukakan oleh King dan Boyatzis (2004) yang menyatakan bahwa menjadi religius dan menjadi spiritual adalah hal yang berbeda, tetapi merupakan dua hal yang berhubungan.

Hasii review yang dilakukan oleh Tanyi (2002) terhadap literatur mengenai spiritualitas yang telah dipublikasikan selama 30 tahun terakhir, menyimpulkan bahwa splritualitas adalah pencarian arti dan tujuan hidup yang dilakukan individu baik melalui agama maupun tidak melalui agama. Davis dkk (2003) menyatakan bahwa spiritualitas berhubungan dengan transendensi tanpa merujuk pada ajaran agama tertentu, sedangkan religiusitas berkonotasi dengan 
kedekatan pada sistem keyakinan agama tertentu. Lebih lanjut Davis dkk (2003) menjelaskan bahwa meskipun religiusitas dan spiritualitas dapat dikonsep secara berbeda, pada kenyataannya kedua istilah tersebut lebih banyak tumpang tindihnya daripada perbedaannya. Dalam banyak kasus religitusitas menyediakan struktur untuk mendapatkan spiritualitas, dalam kasus yang lain spiritualitas tumbuh dalam konteks kerangka kerja religiusitas. Oleh karena adanya tumpang tindih antara religiusitas dengan spiritualitas, maka dalam penelitian ini peneliti menggunakan kedua konsep tersebut.

Benson (2004) menyatakan bahwa banyak terjadi perdebatan dalam melakukan pendefinisian dan pengukuran religiusitas. Barnett diki (1996) menyatakian bahwa religiusitas biasanya didefinisikian dalam istilah: (1) kognitif, yaitu pengetahuan religius dan keyakinan religius; (2) afektif, yaitu kedekatan secara emosional atau perasaan emosional tentang agama; (3) perilaku, yaitu perilaku yang dilakukan individu berkaitan dengan agama, misalnya kunjungan ke tempat ibadah, membaca kitab suci, dan berdoa. Lebih lanjut Barnett dkk (1996) menjelaskan bahwa operasionalisasi konsep religiusitas juga bermacam-macam, misalnya orientasi religius yang dikemukakian oleh Alport, tipologi religiusitas yang dikemukakan oleh Glock dan Stark, kekolotan agama (religious ortadoxy) yang dikemukakan oleh Hunsberger, dan fundamentalisme agama yang dikemukakan oleh $\mathrm{McF}$ arland.

Levine dkk (1995) mendefinisikan dan mengoperasionalkan konsep religiusitas dalam keterlibatan agama yang terdiri dari 3 dimensi, yaitu organisasional (misalnya: kunjungan ke tempat ibadah dan partisipasi dalan kegiatan keagamaan bersama orang lain), non-organisasional (misalnya: membaca kitab suci, berdoa, mendengarkan ceramah di $T V$ dan subjektif (penerimaan nilai-nilai agama dan agama dijadikan acuan dalam kehidupan). Definisi dan Operasionalisasi konsep religiusitas yang hampirsama dengan Levine dkk adalah definisi dan operasionalisasi yang dikemukakan oleh Koenig dkk (1998). Kcenig dkk (1998) mendefinisikian dan mengoperasionalkan konsep religiusitas menjadi 3 dimensi, yaitu religiusitas organisasional, religiusitas nonorganisasional, dan religiusitas intrinsik. Religiusitas or ganisasional digunakan untuk menggambarkan frekwensi berkunjung ke tempat-tempat ibadah atau pelayanan keagamaan. Religiusitas non-organisasional digunakan untuk menggambarkan waktu yang digunakan untuk melakukan aktivitas keagamaan secara pribadi. Religiusitas intrinsik digunakian untuk menggambarkan tingkat keyakinan dan integrasi nilai-nilai agama dalam kehidupan.

Fiori dlik (2006) dalam penelitiannya juga menggunakan operasionalisasi yang hampir sama untuk mengukur religiusitas, yaitu berdasarkan pengukuran subjektif (sebuah pelaporan dirl mengenal keagamaan dan penerimaan agama) dan pengukuran obyektif (organisasional dan non-organisasional). Hackiney dan Sanders (2003) menggunakan definisi religiusitas yang memfokuskan pada aspek sosial dan perilakiu dari agama (institusional), aspek keyakinan (idiologi), dan aspek internalisasi (personal).

Berdasarkan uraian d atas, dapat disimpulkan bahwa spiritualitas adalah pencarian arti dan tujuan hidup yang dilakukan individu baik melalui agama maupun tidak melalui agama, sedangkan religitusitas adalah keterlibatan agama yang terdiri dari 3 dimensi, yaitu organisasional (misalnya: kunjungan ke tempat ibadah dan partisipasi dalan kegiatan keagamaan bersama orang lain), non-organisaslona! (misalnya: membaca kitab suci, berdoa, mendengarkan ceramah di TV dan subjektif (penerimaan nilal-nilai agama dan agama dijadikan acuan dalam kehidupan).

\section{Kesehatan Mental \\ Kesehatan mental telah didefinisikan bermacam-macam dari budaya yang berbeda-beda. Konsep kesehatan mental meliputi kesejahteraan subjektif, self- efficacy, kemadirian (autonomy). kemampuan (competence), aktualisasi diri,}


dan lain-lain. Sulit untuk mendefinisikan kesehatan mental secara umum dari berbagai budaya, tetapi secara umum disepakati bahwa konsep kesehatan mentak lebih luas daripada tidak adanya gangguan mental (WHO, 2001). Meskipun demikian, menurut Wong dkk (2006) beberapa peneliti di lapangan psikologi dan psikiatri mengkonsepkan kesehatan mental dengan ketidakhadiran sakit mental, sedangkan sebagian yang lain mengkonsepkan kesehatan mental lebih pada berfungsi kondisi psikologis individu. Oleh karena itu Wong dkk (2006) kemudian menggunakan kategori kesehatan mental negatif (misalnya: depresi, kecemasan, ketakutan, permusuhan, neurotik, psikotik) dan kesehatan mental positif (misalnya kesejahteraan psikologis, penerimaan díri, hubungan yang baikdengan orang lain, sikap positif pada orang lain, perasaan positif) dalam penelitiannya.

Tindakan yang hampir sama juga telah dilakukan oleh Hackney dan Sanders (2003) dalam studi meta analisis mereka. Mereka mengoperasionalisasikan konsep kesehatan mental dalam 3 konsep, yaitu penyesuaian psikologis yang rendah, kepuasan hidup yang tinggi, dan aktualisasi diri yang tinggi. Keputusan Hacney dan Sanders ini didasarkan pada bervariasinya konsep kesehatan mental yang dipakai dalam penelitian mengenai hubungan religiusitas dengan kesehatan mental yang juga memungkinkan untuk menghasilkan hasil penelitian yang bervariasi.

Berdasarkan uraian di atas disimpulkan bahwa kesehatan mental dapat didefinisikan dengan ketidakhadiran sakit mental, akan tetapi juga dapat dikonsepkan pada berfungsinya kondisi psikologis individu. Oleh karena tu dalam penelitian ini kesehatan mental dapat dikategorikan menjadi dua, yaitu kesehatan mental positif dan kesehatan mental negatif.

\section{MET ODE}

Pencarian Literatur

Pencarian literatur dilakukan menggunakan database online yang tersedia yaitu: EBSCO, ProQuest, Questia, dan Sagepub. Kata kunci yang digunakan adalah religiosity, spirituality, mental health, religiosity and mental health dan spirituality and mental heatth. Semua studi primer yang diperoleh kemudian dipertimbangkan menurut kriteria inklusi sebagai syarat untuk dapat dilakukan meta analisis.

Kriteria inkiusi

1. Tahunpublikasi

Artikel yang digunakan dalam studi ini adalah artikel yang dipublikasikan mulai dari tahun 2000 2006. Kriteria ini dimaksudkan untuk membandingkan hasil studi ini dengan hasil studi meta analisis yang telah dilakukan sebelumnya. Misal studi yang dilakukan oleh Hackney dan Sanders (2003) dilakukan terhadap artikel yang dipublikasikan dari tahun 19902000.

2. Statistik

Sesuai dengan pendapat Lipsey dan Wilson's (Hackney dan Sanders ,2003), statistik ukuran efek yang digunakan dalam meta analisis haruslah berasal dari studi-studi yang sama. Dalam studi meta analisis yang akan dilakukan ini, peneliti ingin mengetahui hubungan religiusitas/spiritualitas dengan kesehatan mental, sehingga statistik ukuran efek yang digunakan adalah korelasi (r). Jika nanti dalam studi diperoleh nilai $F$ atau $t$ maka harus dikonversi ke nilai $r$.

\section{Metode Analisis}

Menurut Hunter dan Schmidt (1990), hasil penelitian yang berbeda-beda mengenai hal yang sama menunjukkan bahwa berbagai studi primer tersebut mempunyai kesalahan. Lebih lanjut Hunter dan Schmidt (1990) menjelaskan bahwa ada 11 kesalahan yang lazim ada dalam penelitian. Dalam penelitian ini hanya 3 kesalahan saja yang akan dikoreksi, yaitu : (1) kesalahan pengambilan sampel, (2) kesalahan pengukuran variabel bebas, (3) kesalahan pengukuran variabel tergantung. Untuk memudahkan dalam melakukan analisis, peneliti melakukan analisis dengan 
dibantu ołeh program meta analisis versi 5.3 yang dibuat oleh Schwarzer (1989) berdasarkan langkah-langkah teknik meta analisis yang dikemukakan olen Hunter dan Schimdt. Test homogenitas yang dipakai dalam penelitian ini menggunakan chisquare, karena menurut Hunter \& Schimdt (1990) chi-square inl yang sekarang banyak dipakai untuk tes homogenilas.
HASIL ANALISIS

1. Karakteristik Sampel Penelitian

Ada 101 studi primer yang berhasil dikumpulkan. Berdasarkan pada kriteria inklusi, ada 20 studi mengenai hubungan religiusitas/spiritualitas dengan kesehatan mental yang dapat dipakal dalam studi meta analisis ini. Dua puluh artikel yang diperoleh memiliki 93 koefisien ukuran efek. Gambaran sampel penelitian secara ringkas dapat dilihat pada tabel 1.

Tabel 1. Ringkasan Karakteristik Sampel Penelitian

\begin{tabular}{|c|c|c|c|c|c|c|c|c|c|c|c|}
\hline No & $\mathbf{N}$ & Subyek & $r_{x}$ & ra & $r_{\alpha}$ & No & $\mathbf{N}$ & Subyek & $\mathbf{r}_{\mathrm{ry}}$ & $\mathrm{Ix}$ & $r_{r}$ \\
\hline 1. & 303 & Mhs & $-0.14^{\prime}$ & 0.86 & 0.88 & 48 & 20 & Remeja & $-0.45^{\circ}$ & $=$ & $=$ \\
\hline 2. & $\frac{303}{\pi}$ & $\begin{array}{l}\text { Mrs } \\
\text { Lansia }\end{array}$ & $\begin{array}{c}0.11 \\
0341^{*}\end{array}$ & 0.86 & 0.92 & $\begin{array}{l}49 \\
50\end{array}$ & $\begin{array}{l}117 \\
117\end{array}$ & $\begin{array}{l}\text { P. Hiv } \\
\text { P.Hiv }\end{array}$ & $\begin{array}{c}0.13 \\
0.44^{+*}\end{array}$ & $\begin{array}{l}0.96 \\
0.86\end{array}$ & $\begin{array}{l}0,80 \\
0,80\end{array}$ \\
\hline 4 & 71 & Lansia & 0385 & - & - & 51. & 400 & mhs & 0.013 & $=$ & 0.987 \\
\hline 5. & 180 & Lansia & $031 \%$ & 0.745 & 0.77 & 52. & 659 & Demortima & $-4,8^{\circ}$ & 0,643 & 0,743 \\
\hline 6 & 180 & Lansia & p.56**: & 0,745 & 0.77 & 53. & 659 & Dewasa & $-0,00^{*}$ & 0,643 & $0 B 35$ \\
\hline 7. & $\mathrm{EBO}$ & Lansisia & $0.29^{-4}$ & 0,745 & 0.77 & 54. & 155 & Dewasa & -0.07 & 0.675 & 0.81 \\
\hline 8. & 180 & Lannsia & 0.10 & 0,745 & 0.77 & 55 & 155 & Dewasa & 006 & - & 0.70 \\
\hline $\begin{array}{l}9 . \\
10 .\end{array}$ & $\begin{array}{l}190 \\
160\end{array}$ & $\begin{array}{l}\text { Lansia } \\
\text { Lantis }\end{array}$ & $\begin{array}{c}0.52^{-} \\
0.39-1\end{array}$ & $\begin{array}{c}0,745 \\
0,81\end{array}$ & $\begin{array}{l}0.77 \\
0.80\end{array}$ & $\begin{array}{l}56 . \\
57 .\end{array}$ & $\begin{array}{l}155 \\
570\end{array}$ & $\begin{array}{c}\text { Dewasa } \\
\text { mhs }\end{array}$ & $\begin{array}{c}-0.17 \\
-0.144\end{array}$ & - & 0.90 \\
\hline 11 & 150 & Lansia & $0.39^{-}$ & 0,81 & 0.80 & 58. & 570 & mhs & $-0.123^{14}$ & $\begin{array}{l}0.89 \\
0.89\end{array}$ & 0.90 \\
\hline 12. & 160 & Lansia & $0.44^{-\infty}$ & $0,8 \mathrm{t}$ & a.go & 59. & 570 & mhe & $-0.115 *$ & 0.69 & 0.89 \\
\hline 13. & 160 & Lansia & $0.32^{m}$ & 0,87 & 0.50 & 60 & 570 & mhs & -0.026 & 089 & 0.93 \\
\hline 14. & 160 & Lansia & $0.31=$ & 0,83 & 0.80 & 61. & 122 & Lansia & $0.25^{--}$ & 0,69 & 0,89 \\
\hline 15. & 46 & Mhs & $-0.43^{* *}$ & 0.95 & 0.52 & 62 & 12 & Lansia & $0.26^{+\infty}$ & 0.83 & 0.89 \\
\hline 16. & $A B$ & Whs & 007 & 0.95 & 0.64 & 63 & 12 & Lansia & $0.27^{* 4}$ & - & 0,69 \\
\hline 17 & 48 & Mhs & $0.0 t$ & 095 & 0,87 & 64. & 122 & Lanscia & 0.13 & $\cdot$ & 0.89 \\
\hline 18. & 48 & Mhs & $0: 26$ & 0.95 & 0.68 & 65 & 122 & Lansiga & $=0,01$ & 0.69 & 0,82 \\
\hline 19. & 48 & Whs & 0.26 & 0.95 & 0.77 & 66 & 122 & Lansia & $-0,48$ & 0.83 & 0.82 \\
\hline 20 & 48 & Mhts & 0.21 & 0,95 & 0.82 & 67. & 122 & Larela & $-0,24$ & 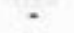 & 0,82 \\
\hline 21. & 105 & Allel & 0,02 & - & 0,89 & 69. & 122 & Laneip & $-0,03$ & - & 0.82 \\
\hline 22 & 105 & Atret & $-0,10$ & - & 0,84 & 69. & 3แBJ & Dewasa & $0.11^{-\infty}$ & 0.82 & 0.60 \\
\hline 23 & 105 & Ater & 0,02 & - & 0.70 & To. & $\uparrow 11$ & Denvaca & $-0.53^{.4}$ & 090 & 0.80 \\
\hline 24 & 105 & Attet & $-0,06$ & - & 0,88 & 71. & 111. & Dewasa & 0.33 & 090 & 0.85 \\
\hline 25. & 105 & Atlet & $-0,09$ & - & 0,84 & 72. & 1.056 & Lakj-L aki & $0,282^{-}$ & 089 & 0.77 \\
\hline 26. & 105 & Attat & $-0,04$ & - & $0 ; 70$ & 73. & 1.056 & Laki-Lakī & $0334=$ & 089 & 0.86 \\
\hline 27. & 105 & Atjet & $-0,10$ & - & 0,88 & 74. & 1754 & Wranila & $0256^{\circ}$ & 0.89 & 077 \\
\hline 28 & 105 & Atiet & $-0,21$ & - & 0,84 & 75. & 1.154 & Wanila & $0.311=$ & 0.89 & 0.86 \\
\hline 29 & 105 & Atiget & $-0,04$ & - & 0,70 & 76. & 105 & Dewasa & -0.046 & 0.89 & 0.88 \\
\hline 30 & 86 & Mhs & $D D F$ & - & 0.89 & 77. & 305 & Dewasa & 0.014 & 0.97 & 0.88 \\
\hline 31. & 85 & Mhs & $-0,23^{*}$ & - & 0,80 & 78. & 305 & Dewasa & $-0.194^{\circ}$ & 0.83 & 0,88 \\
\hline 32. & 85 & Whs & $0.22^{\circ}$ & - & 0.09 & 79. & 305 & Denasa & -0.335 & 0.74 & 0,89 \\
\hline 33 & 85 & Mhs & $-0.3 f^{\circ}$ & - & 0,80 & 80 & 305 & Dewasta & 0.095 & 0.89 & 0.86 \\
\hline 34. & 85 & Whs & 001 & - & 0.89 & 81. & 305 & Dewas? & $0.144^{r}$ & 0.97 & 0.86 \\
\hline 35. & 85 & Hhs & $=0.14$ & - & 0,80 & 82. & 305 & Dewasa & $-0.233^{r}=$ & 0.83 & 0.86 \\
\hline 36 & 337 & Dewża & -004 & - & 080 & 83. & 305 & Dewasa & $-0332^{\ldots}$ & 0.74 & 086 \\
\hline 37. & 337 & Dewasa & $-0.19^{\circ}$ & $0 E 9$ & 0,80 & 64 & 305 & Dewasa & 0.105 & 0.8 & 0.88 \\
\hline 38 & 337 & Dewrsa & -009 & $\cdot$ & $O B O$ & 85 & 305 & Dewass & 0. 103 & 0.97 & 0.88 \\
\hline 39. & $100\{\mathrm{~A}\}$ & Dewasa & 0.137 & - & - & 86. & 305 & Dewasa & $-0.226=$ & 083 & 088 \\
\hline 40. & $100\{A\}$ & Dewasa & $-0,05$ & - & - & 87. & 306 & Depwast & $-0,330^{\circ+1}$ & D. 74 & 0.88 \\
\hline $4 t$. & $100(A)$ & Dewasa & 0,357 & $\cdot$ & $\cdot$ & B8: & 305 & Dewase & 0.042 & 0.89 & 0.81 \\
\hline 42. & $100(A)$ & Dewa sa & $-0,207$ & - & - & 69 & 305 & Dewaza & 0.055 & 0.97 & 0.81 \\
\hline 43. & 100 (B) & Dewạga & 0,097 & - & - & 90 & 305 & Dowasa & $-0,199^{\prime \prime}$ & 0.80 & 0.81 \\
\hline 44. & $100(B)$ & Dewrasa & $-0,03$ & - & - & 91. & 305 & Denasa & $-0.202=$ & 0.74 & 0.81 \\
\hline 45 & $100(B)$ & Dewasa & 0,390 & - & - & 92 & 67 & P HW & 0.18 & $\cdot$ & - \\
\hline 46. & 100 (B) & Dewasa & $-0,174$ & - & - & 93 & 107 & P.HIV & $0.31=$ & - & - \\
\hline 47. & 20 & Remaja & $-0.58-$ & - & - & & & & & & \\
\hline
\end{tabular}


1. Pengkategorian dan Pengkodean

Seperti telah diuraikan pada bagian pengantar bahwa hasil-hasil penelitian mengenai hubungan religiusitas/spiritualitas dengan kesehatan mental yang bervariasi diduga karena konsep dan operasionalisasi/pengukuran religiusitas dan kesehatan mental yang multidimensional. Kategorisas| dalam penelitian ini berbeda dengan penelitian yang dilakukan oleh Hackney dan Sanders (2003) karena Hackney dan Sanders (2003) sendiri mengatakan bahwa salah satu kelemahan penelitiannya adalah adanya tumpang tindih antara kategori yang satu dengan yang lainnya. Oleh karena itu dalam studi meta analisis ini dilakukan pengkategorian untuk mengelompokkan studi-studi yang diper oleh. Berdasarkan studi primer yang diperoleh, variabel bebas dalam penelitian dikategorisasikan menjadi 5 kategori, yaitu : religiusitas organisasional (kode 1), religiusitas non-organisasional (kode 2), dan religiusitas intrinsik (kode 3 ), religiusitas multidimensional (kode 4), dan spiritualitas (kode 5). Variabel kesehatan mental dikategorisasikan menjadi 2 kategori, yaitu kesehatan mental positif (kode 1) dan kesehatan mental negatif (kode 2). Hasil pengkodean dapat ditihat pada tabel 2.

Tabel 2. Hasil Pengkodean dan Daftar Studi Primer Yang digunakan Dalam Meta Analisis

\begin{tabular}{|c|c|c|c|c|c|c|}
\hline No & Ponulis & $\begin{array}{l}\text { Jumlah } \\
\text { Ukuran } \\
\text { efta }\end{array}$ & $\mathbf{N}$ & Subyek & $\begin{array}{c}\text { Koding } \\
\text { Rel'rgiusitas } \\
(x)\end{array}$ & $\begin{array}{l}\text { Koding } \\
\text { Kesehotan } \\
\text { Mental } \\
\text { \{Y\} }\end{array}$ \\
\hline 1. & Young ok (2000) & 2 & 303 & Mahesiswa & 5 & 2 \\
\hline 2. & Meisenhelder \& Chandler (2000) & 2 & 71 & Lanșia & 2,3 & 1 \\
\hline 3. & Fry $(2000)$ & 10 & $180 \approx 760$ & Lansia & $1,2,3,5$ & 1 \\
\hline 4. & Lewis (2001) & 6 & 48 & Mahasiswa & 3 & 2 \\
\hline 5. & Storch dk (2002) & 9 & 105 & Allet Wania & $1,2,3$ & 2 \\
\hline 6. & Harris. dk (2002) & 6 & 85 & Mahasiswa & $1,2,3$ & 1.2 \\
\hline 7. & Nochey \& Woodtum (2002) & 3 & 337 & Dewasa & $1,2,3$ & 2 \\
\hline B. & Tsuang dkk (2002) & 8 & $100(A) 8100(B)$ & Dewnasa & 3,5 & 1,2 \\
\hline 9 & Davis dkk (2003) & 2 & 20 & Remafa & 3,5 & 2 \\
\hline 10. & Coleman (2003) & 2 & 177 & P. Hiv & 3.5 & 1 \\
\hline 11. & Francis \& Jacson (2003) & 1 & 400 & Mathasiswa & 3 & 2 \\
\hline 12. & Jang 8 Johnson (2004) & 2 & 659 & Dewase & 4 & 2 \\
\hline 13. & Wink \& Scolt (2005) & 3 & $15 \mathbf{1}$ & Denatata & 4 & 1,2 \\
\hline 14. & Al-Sabwah \& Abdej-Khalek (2006) & 4 & $5 A$ & Mahtsḯswa & 4 & 2 \\
\hline 15. & Ardght \& Konng (2006) & 8 & 122 & Lanșia & $1,2,3$ & 1,2 \\
\hline 16. & Fien dkk (2006) & 1 & 3480 & Dawest & 4 & 1 \\
\hline 17. & Craig didk (2006) & 2 & 111 & Dewass & 5 & 1,2 \\
\hline 18. & Abdel Khalek (2006) & 4 & $1.056 \& 1154$ & $\begin{array}{l}\text { Lakj-laki } \mathrm{E} \\
\text { Wanita }\end{array}$ & 4 & 1 \\
\hline 19. & Lonczak okk (2006) & 16 & 305 & Dewasa & $1,2,3,5$ & 2 \\
\hline 20. & Philips okk (2006) & 2 & 107 & P HN & 3,5 & 1 \\
\hline
\end{tabular}


3. Hasil analisis setelah dilakukan koreksi tehadap kesalahan pengambilan sampel dan kesalahan pengukuran.

Berdasarkan pengkategorian yang telah dilakukan, diperoleh 10 ketompok studi yang di analisis. Hasil analisis secara lengkap dapat dilihat pada tabel 3.

Tabel 3. Matriks Hasil Analisis

\begin{tabular}{|c|c|c|}
\hline \multirow{2}{*}{ Variabel bebes } & \multicolumn{2}{|c|}{ Variabel Tergartung } \\
\hline & Kesehatan Mental Positif & Kesehatan Mental Negalif \\
\hline $\begin{array}{l}\text { Religiusitas } \\
\text { Organisasional }\end{array}$ & $\begin{array}{c}\text { Ukuran efek: } 4, N=547 \\
\text { Korelasi sesungguhnya } ; 0,345 \\
C l: 0,116 \quad 0,573 \\
\text { Chi-square : } 9,752, p<0,05 \text { (1-telerogen) }\end{array}$ & $\begin{array}{c}\text { Ukuran efek: } 10, N=2079 \\
\text { Korelasi sesungguhnya; }-0,012 \\
\text { CA:-0,158 } 0,134 \\
\text { Ch-square: } 18,507, p<0,05 \text { (Heterogen) }\end{array}$ \\
\hline $\begin{array}{l}\text { Religiusitas } \\
\text { Non-organisasional }\end{array}$ & $\begin{array}{c}\text { Ukuran elek : } 5, \mathrm{~N}=6.18 \\
\text { Korelasi sesungguhnya : } 0,445 \\
\mathrm{a}: 0,112 \quad 0,778 \\
\text { Chi-square: } 20,417 \mathrm{p}<0,05 \text { (Hzter ogen). }\end{array}$ & $\begin{array}{c}\text { Ukuran efek: } 10, N=2079 \\
\text { Korelasi sesungguhmya : }-0,188 \\
\text { Cl: }-0,316 \quad 0,060 \\
\text { Chi-square :16,416, } p>0,05 \text { (Homogen) }\end{array}$ \\
\hline $\begin{array}{l}\text { Religiusitas } \\
\text { Intrinsik }\end{array}$ & $\begin{array}{c}\text { Ukuran efak: } 12, \mathrm{~N}=1504 \\
\text { Korelasi sesungguhmya : 0,227 } \\
\mathrm{Cl}:-0,137 \quad 0,591 \\
\text { Chi-square : } 50,048 \mathrm{p}<0,05 \text { (Hetemegen) }\end{array}$ & $\begin{array}{c}\text { Ukcuran elek: } 21, N=3109 \\
\text { Korelasi sesungguhnya: }-0,212 \\
\text { CI:-0,577 } 0,153 \\
\text { Chi-square : } 98,149, p<0,05 \text { (Heterogen) }\end{array}$ \\
\hline $\begin{array}{l}\text { Religiusitas } \\
\text { Multidimensional }\end{array}$ & $\begin{array}{c}\text { Uluran efik ; 6. } \mathbf{N}=8055 \\
\text { Korelasi sesungguhnya:0,253 } \\
\mathrm{Cl}: 0,006 \quad 0,501 \\
\text { Chi-square: } 101,440 \mathrm{p}<0,05 \text { (Heterogen) }\end{array}$ & $\begin{array}{c}\text { Ukuran efek: } 8, N=3908 \\
\text { Korelasi sesungguhnya : }-0,130 \\
\text { O : }-0,218=-0,042 \\
\text { Chi-square: } 13,477, p>0,05 \text { (Homogen) }\end{array}$ \\
\hline Spiritualitas & $\begin{array}{c}\text { Uhuran efek : } 7, N=875 \\
\text { Korelasi sesungguhrya :0,470 } \\
\text { Cl : } 0,449 \quad 0,490 \\
\text { Chi-scuare: } 7,247 \mathrm{p}>0,05 \text { (Homggen) }\end{array}$ & $\begin{array}{c}\text { Ukuran efek: } 10, N=2157 \\
\text { Korelasi segungguhnya ; }-0,046 \\
C ;-0,385 \quad 0,294 \\
\text { Chi-square: } 61,992, \mathrm{e}<0,05 \text { (Heterogen) }\end{array}$ \\
\hline
\end{tabular}

Keterangan : $\mathrm{Cl}=$ Confidence Inlerval = interval kepercayaan

Berdasarkan tabel $3 \mathrm{~d}$ atas terlihat bahwa setelah dilakukan kafegorisasi baik pada variabel bebas maupun variabel fergantung, hubungan antara religiuslias/spiritualitas sebagai variabel bebas dengan kesehatan mental sebagai variabel fergantung menjadi lebih jelas. Adapun penjelasan hasil analisis secara rinci adalah sebagai berikut:

a. Korelasi populasi yang sesungguhnya antara religiusitas organisasional dengan kesehatan mental positif adalah 0,345 dengan interval kepercayaan 95\%: 0,116 0,573 . Nilai chi-square 9,752 dengan $p<$ 0,05 menunjukkan heterogenifas. Heterogenitas yang terjadi menunjukkan adanya variabel moderator.

b. Korelasi populasi yang sesungguhnya antara religiusitas non-organisasional dengan kesehatan mental positif adalah 0,445 dengan interval keper cayaan $95 \%$ : $0,112 \quad 0,778$. Nilai chi-square 20,417 dengan $p<0,05$ menunjukkan heterogenitas. Heferogenitas yang terjadi menunjukkan adanya variabel moderator.

c. Korelasi populasi yang sesungguhnya antara religiusitas intrinsik dengan kesehatan mental positif adalah 0,227 dengan interval kepercayaan $95 \%$ : $0,137 \quad 0,591$. Nilai chi-square 50,048 dengan $p<0,05$ menunjukkan heterogenitas. Heterogenitas yang terjadi menunjukkan adanya variabel moderator. 
Hasil penelitian yang diperoleh dalam penelitian ini dapat dijelaskan dari beberapa hasil penelitian dan pendapat. Misalnya hasil penelitian dari Rowatt dan Kirkpatrick (2002). Hasil penelitian mereka menunjukkan adanya hubungan yang positif antara orientasi religius intrinsik dengan kelekatan aman (secure aftachment) pada Tuhan. Sebaliknya, ada hubungan negatif antara orientasi religius intrinsik dengan kelekatan cemas (anxiety attachment) pada Tuhan. Hal ini menunjukkan bahwa orang yang memiliki orientasi religius intrinsik memiliki kelekatan aman dengan Tuhan. Kelekatan aman dengan Tuhan ini kemudian membawa kepada perasaan yang positif. Dengan kata lain dapat disimpulkan bahwa orang yang memiliki orientasi religius intrinsik (salah satu dimensi religiusitas) akan memiliki perasaan positif. Salah satu perasaan positif seseorang adalah kebahagiaan yang merupakan salah satu manifestasi dari kesehatan mental positif. Sebaliknya, orang yang orientasi religius intrinsiknya rendah, dia akan memiliki kelekatan cemas pada Tuhan, dan hal inf akan membawa pada kesehatan mental yang negatif.

Mattis (2002) dalam penelitian kualitatifnya menemukan bahwa ternyata spiritualitas dan religiusitas digunakan oleh subjek penelitiannya untuk menerima kenyataan hidup atau lebih tepatnya untuk menjembatani antara keinginan yang ada dalam dirinya dengan realita yang ada. Dengan demikian individu akan selalu merasa tenang karena pada akhirnya dia bisa menerima kenyataan yang ada. Dengan demikian individu akan memiliki kesehatan mental yang baik. Dalam penelitian Mattis juga ditemukan penggunaan spiritualitas untuk memaknai kehidupan, untuk mendapatkan tujuan hidup, transenden, menjawab pertanyaan-pertanyaan eksistensial, berdialog, bertindak sesuai prinsip hidup, dan untuk meraih pertumbuhan yang optimal. Hal-hal tersebut merupakan kunci untuk meraih kesehatan mental, sehingga orang yang memiliki spiritualitas akan memiliki kesehatan mental yang baik/positif.
Pargament (James dan Wells, 2003) menjelaskan hubungan religiusitas dengan kesehatan mental melalui teori pengatasan masalah (coping). Berkaitan dengan coping, religiusitas mempunyai peran dalam tiga level. Level yang pertama, agama sebagai bagian dari coping. Agama sebagai elemen dari pengatasan masalah, dapat melalui aktivitas kognitif (misalnya individu mengambil hikmah dari peristiwa yang dialaminya), melalui perilaku (misalnya berdoa), dan dapat melalui respon kolaboratif (misalnya kepasrahan pada Tuhan). Level yang kedua, kemampuan agama untuk membentuk proses coping. misalnya agama mempengaruhi peristiwa dalam hidup seperti pernikahan. Level yang

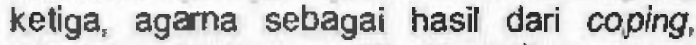
misalnya karena sakit kemudian orang kembali lagi ke ajaran agamanya.

James dan Wells (2003). menjelaskan korelasi antara religiusitas dengan kesehatan mental dari kerangka kerja kognitif. Menurut mereka, setidaknya ada dua mekanisme yang dapat digunakan untuk menjelaskan hubungan religiusitas dengan kesehatan mental. Yang pertama, keyakinan agama (skema) menyediakan model mental yang dapat digunakan individu untuk membimbingnya melakukan penilaian pada peristiwa dalam kehidupannya. Yang kedua, keyakinan agama (skema) menyediakan model mental yang dapat digunakan individu untuk mengatur proses berpikimya.

Hasil meta analisis ini dapat digunakan oleh terapis/konselor sebagai referensi dalarn menangani atau berhadapan dengan klien, terutama klien yang religius atau beragama. Untuk di Indonesia, temuan ini lebih tepat digunakan oleh terapis karena sebagian besar penduduk Indonesia beragama. Meskipun demikian hasil penelitian ini harus digunakan berhati-hati karena hasil uj homogenitas menunjukkan bahwa homogenitas hanya ditemukan pada: (1) hubungan spiritualitas dengan kesehatan mental positif, (2) hubungan religiusitas nonorganisasional dengan kesehatan mental negatif, dan (3) hubungan antara religiusitas multidimensional dengan kesehatan mental 
negatif. Sedangkan tes homogenitas hubungan dimensi religiusitas yang lain baik dengan kesehatan mental positif maupun dengan kesehatan mental negatif menunjukkan adanya heterogenitas. Heterogenitas ini menunjukkan adanya bias yang sistematis, atau adanya variabel moderator. Misanya dalam penelitian Fiori dkk (2006) ditemukan bahwa jenis kelamin, suku, dan umur berpengaruh pada religiusitas.

\section{DAFTAR PUSTAKA}

Abdel-Khalek,A.M. 2006. Happiness, Health, and Religiosity: Significant Relations. Mental Health, Religion, \& Cullure, Vol. $9,1,85-97$

Al-Sabwah, M.N. and Abdel-Khalek A.M. 2006. Religiosity and Death Distress in Arabic College Students. Death Studies, Vol, 30, 365-375

Ardelt, $M$ and Koenig, C.S. 2006. The Role of Religion for Hospice Patients and Relatively Healthy Older Adults. Research on Aging, Vol. 28, 2, 184 215

Barrnet, T, Ken, B, and Gene, B. 1996. Religiosity, Ethical Ideology, and Itentions to Report A Peer's Wrongdoing. Journal of Bussiness Ethics, Vol. 15, 11, 1161-1175.

Benson, PL. 2004. Emerging Themes in Research on Adolescent Spiritual and Religious Development. Applied Developmental Science, $V$ d. 8, 1, 47 50

Coleman, C.L. 2003. Spirituality and Sexual Orientation: Relationship to mental well-Being and Functional Health Status. Journal of Advanced Nursing. Vol $43,5,457-464$

Commerford, M.C, and Reznikoff, M. 1996. Relationship of Religion and Percieved Social Support to SelfEsteem and depression in Nursing Home Residents. The Journal of Psychology, Vol. 130, 1, 35-51
Craig, C. Weinert, C., and Walton, J. 2006. Spirituality, Cronic lilness, and Rural Life. Journal of Holistic Nursing, Vol.24, 1, 27-35

Davis, T.L., Kerr,B.A, and Kupius S.E.R. 2003. Meaning, Purpose, And Religlosity in At-Risk Youth: The Relationship Between Anxiety And Spirituality. Journal of Psychology and Theology. Vol.31, 4, p. 356

Elliasen, A.H. Taylor, J. and Lloyd, D. 2005. Subjective Religiosity and Depression in the Transition to Adulthood. Joumal For The Scientific Study of Religion, Vol $44,2,187-199$

Fiori, KL, Brown, E.F., Cortina, K.S., and Antonucci, T.C. 2006. Locus of Control as a Mediator of The Relationship Between Religiosity and Life Satisfaction: Age. Race, and Gender Differences. Mental Health, Religion \& Culture, vol.9,3, 239263

Francis, L.J. dan Jackson, C.J. 2003. Eysenck's Dimensional Model of Personality and Religion: Are Religious People More Neurotic? Mental Health, Religion \& Culture. Vol.6, 1, 87-100

Fry, P.S. 2000. Religious Involvement, Spirituality And Personal Meaning For Life:Existential Predictors of Psychological Wellbeing In Community-Residing And Institutional Care Elders. Aging And Mental Heath, 4, 4, 375-387

Hackney, C.H., and Sanders, G.S., 2003. Religiosity and Mental Health: MetaAnalysis of Recent Studies. Joumal for The Scientific Study of Religion, Vol $42,1,4355$

Harris, J.l. Schoneman S.W., and Carrera S.R. 2002. Approaches To Religiosity related To Anxiety Among College Students. Mental Health, Religion \& Culture, Vor 5, 3, 253-265

Hunter, J.E., and Schmidt, F.L., 1990. Method's of Meta-Analysis. Newbury Park, California: Sage Publications. 
James, A, and Wells, A, 2003. Religion an Mental Health: Towards a CognitiveBehavioral Framework. British Journal of Health Pychology, Vol. 8, 359-376.

Jang, S.J. and Johnson, B.R. 2004. Explaining Religious Effects on Distress Among African Americans. Joumal for Scientific Study of Religion. Vol $43,2,239-260$

Hayes, M.A. and Cowie, H. 2005. Psychology and Religion: Maping The Relationship. Mental Health, Religion, \& Culture. Vol 8, 1, 2733.

King, P.E, and Boyatzis, C.J. 2004. Exploring Adolescent Spiritual and Religious Development: Current and Future Theoretical and Empirical Perspectives. Applied Developmental Science, Vol. 8, 1, 26 .

Koenig, H.G., George, L.K, and Petterson, B.L. 1998. Religiosity and Remission of Depression in Medically III Older Patients. The American Journal of Psychiatry, Vol 155, 4, 536543.

Lewis, C.A. 2001. Cultural Stereotype of The Efects Of Religion on Mental Health. British Joumal Of Medical Psychology, Vol. $74,359-367$

Lonczak, H.S., Clifaseft, S.L., Marlatt, G.A., Blume A.W., and Donovan, D.M. 2006. Religious Coping and Psychological Functioning in a Correctional Population. Mental Health, Religion, \& Cullure, vol. 9,2, 171-192

Maltby, J, Lewis, C.A, and day, L. 1999. Religious Orietation and Psychological Well-Being. The Role of The Frequency of Personal Prayer. Bitish Joumal of Health psychology, 4, 363-378

Mattis, J.S. 2002. Religion and Spirituality in The Meaning Making and Coping Experiences of African American Women: A Qualitative Analysis. Psychology of Women Quarterly, Vol 26,309-321
Meisenhelder, J.B. and Chandler, E.N. 2000. Faith, Prayer, and Health Outcomes in Elderly Native Americans. Clinical Nursing Research, Vol. 9 No.2, 191203

Nooney, J. and Woodrum, E. 2002. Religlous Coping And Church-Based Social Support As Predictors of Mental Health Outcomes: Testing A Conceptual Model. Journal For Scientific The Study of Religion. Vo. $141,2,359-368$

Peacock, J. R, and Poloma, M.M. 1999. Religiosity and Life Satisfaction Across The Life Course. Social Indicators Research, Vol.48,3,p321

Phillips, K.D., Mock, K.S., Bopp, C.M., Dudgeon, W.A., Hand, G.A. 2006. Spiritual Well-Being. Sleep Disturbance, And Mental And Physical Health Status in HiV-Infected Individuals. Issues in Mental Health Nursing, Vol27, 125-139

Rowatt, W.C, and Kirkpatrick, L,A, 2002. Two Dimentions of Attachment To God and Their Relation o Affect, Religiosity, and Personality Constructs. Joumal for The Scientific Study of Religion, Vol $41,4,637-651$.

Schafer, W.E. 1997. Religiosity, Spirituality, and Personal Distress Among College Students. Joumal of College Student Development, Vol 38, 6, 633-645

Schwarzer, R. 1989. Manual Meta-Analysis Programs. From. http:/lwebs $\underline{\underline{u}}$ =

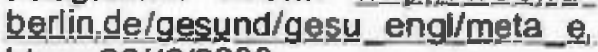
htm. 26/12/2006

Sharma, M. 2006. Religiosity and Substance Abuse: Need for Systematic Research. Joumal of Alcohol and Drug Education, Vol. 50, 1, 1-5

Storch, EA, Storch J.B., Welsh, E, and Okun, A. 2002. Religiosity and Depression in Intercollegiate Athletes. College Student Joumal, Vol. 36, 4, p. 526 
Tanyi, RA, 2006. Spirituality and Family Nursing: Spiritual assessment and interventions for Families. Joumal of Advanced Nursing, Vol. 53, 3, 287 294.

"Tsuang, M.T., Williams, W.M., Simpson, J.C., and Lyons, M.J. 2002. Pilot Study of Spirituality and Mental Health in Twins. Am J psychiary, Vol 159, 3 , 2002

WHO. 2001. Chapter 1: A public health approach to mental health htto://www.who.inthwr/2001/chapter1 len/print.htm!.04/01/2007

Wink, P. and Scott, J. 2005. Does Religiousness Buffer Against the Fear of Death and Dying in Lałe Adulthood? Findings from A Longitudinal Study.
The Joumals of Geronfology: Series B: Psychological Sciences and Social Sciences Vol 60B, 4, 207215

Wong, Y.J. Rew, L, and Slaikeu, K.D. 2006.A Systematic Review of Recent Research on Adolescent Religiosity/Spirituality and Mental Health. Issue in Mental Health Nursing, Vol27, 161-183

Young, J.S., Cashwell, C.S., and Shcherbakova, J. 2000. The Moderating Relationship of Spirituality on Negative Life Events and Psychological Adjus tment. Counseling and Value, Vol45, 1, p. 49 